This essay is part of IJARBM's special issue

"Contemporary Applied Business Research

in Light of Standard Academic Literature".

\title{
Discrimination Versus Diversity: The Challenges and Opportunities
}

\author{
Phyllis Dirrler \\ phyllis.dirrler@yahoo.com \\ MATE Hungarian University of Agriculture and Life Sciences - Kaposvár \\ Campus, Kaposvár, Hungary \\ https://doi.org/10.51137/ijarbm.2022.3.1.8
}

\begin{abstract}
Despite the controversial results of Becker (1993), there are aspects of his work, which can be considered as relevant, even in today's globalized world. Even though, within this essay the main argument is that humans behave more irrationally than suggested by the traditional rational theory or Becker's (1993) findings, it still needs to be highlighted that some of the problems pointed out by Becker (1993) in terms of discrimination can still be considered today, when researching diversity and conflict.
\end{abstract}

Keywords - Discrimination, Diversity, Becker, Challenges

\section{Discrimination: A Status-Quo}

Theoretically in a rational market, employers should only consider the productivity of employees and customers only the quality of a good or service. In daily life however, discrimination at the workplace and within the market exists, leaving potential for alternative explanations. Becker (1993) incorporates discrimination coefficients in form of race and gender in his work to provide explanations for the described phenomenon. According to his work, discrimination is not only based on preferences, but on other factors such as the amount of minority members and the investment of human capital. He argues that discrimination is less to not at all harmful to the majority, if they outnumber minorities significantly, because it does not have any noticeable effect on incomes or prices. He further claims that the whole concept of discrimination works, because minority members cannot provide sufficient skills so that companies could focus on only using the minority employees and highlights that the discrimination of employees and customers is even more present in the long-run and will not disappear, unless there are enough segregated markets and firms. If minorities are able to invest in human capital, it is possible to overcome some of the gaps related to income for example, as introduced by the example of women. While the aim of this essay is not to generally question the findings and statements of Becker (1993), it still needs to be highlighted that fortunately diversity has started to become part of the market, without the need for segregated firms or markets 
for minorities. Generally, diversity can be defined as any attribute people can use to differentiate themselves from other people (Phillips and O'Reilley 1998; Mannix and Neale 2005). Some researchers only focus on race, gender and cultural attributes (Cross et al. 1994), while others strengthen a broader definition, including all possible variables (Thomas and Ely 1996). In contrast to the analysis of Becker (2005), minorities are part of today's businesses and workplaces have become diverse (Mannix and Neale 2005), leading to the assumption that employers behave in a rational way to maximize their benefits. The advantages of diverse teams are expected to be an increase in the variety of ideas, perspectives and approaches, leading to more creativity and better performances (Mannix and Neale 2005). However, the reality often shows that there is still social division, often resulting in negative results (Mannix and Neale 2005) in terms of communication, social integration and conflict (Jehn et al. 1999; Pelled et al. 1999). Within this essay, the goal is to look for alternative explanations for the difficulties of diverse teams, with a specific focus on conflict, which go beyond a pure preference for discrimination and the lack of suffering from discrimination, as suggested amongst others by Becker (1993). Furthermore, first findings are presented on how to overcome these challenges, reaching beyond the investment in human capital.

\section{Theoretical Findings on Diversity}

Major theoretical findings on the background, causes and effects of diversity are social categorization, social attraction and similarity theory. Social categorization theory claims that differences in the demographic composition of teams influence group processes and performance (Phillips and O'Reilley 1998). It is based on the assumption that individuals perform comparisons and categorize themselves and others according to salient attributes, as for example age, race, membership, status or religion (Tajfel 1981; Turner 1987). Principally, individuals view themselves as more attractive than others and can use the comparison procedure to see themselves as a member of a group (Phillips and O'Reilley 1998). By doing so, it is possible to perform stereotyping (Tajfel 1981) and to view in-group and out-group members, whereas out-group members are automatically regarded as less trustworthy, honest or cooperative (Tajfel 1982). Consequently, some researchers conclude that heterogeneity in teams can lead to decreased satisfaction, increased turnover desires, reduced communication and cooperation and ultimately more conflict (e.g. (Triandis et al. 1994). Similarity attraction theory strengthens these findings and argues that individuals always prefer to work or interact with similar ones, if they can decide themselves (e.g. (Burt and Reagans 1997). In line with the different attributes of diversity, similarity can vary from attitudes and values to demographic variables (Byrne et al. 1966). Again, researchers claim possible negative outcomes to be observed in form of incorrect communication and message distortion (Barnlund and Harland 1963), general performance declines and higher turnover rates (Jehn et al. 1999; Jackson et al. 1993). Similarity theory strengthens these findings by stating that individuals are more attracted to and favor more similar people 
(Byrne 1971) and consequently cooperate more with people sharing similar values and beliefs (Williams and O'Reilly, III 1998). The introduced theories indicate that even if people do not actively get involved in discrimination, prejudices remain, and we naturally form in-group and out-groups and generally prefer the interaction with similar others. This is in contradiction to the theory of individual rational choice and also challenges some of the statements of Becker (1993).

\section{Diversity: A Driver for Conflict}

As already shortly introduced above, diversity can foster negative outcomes, such as increased conflict. Diversity based on sex is reported to cause more conflict, interpersonal tension and less friendliness (Alagna et al. 1982), thus generally having harmful consequences on group processes (Phillips and O'Reilley 1998). Considering ethnicity, race or cultural diversity, there is one group of researchers presenting results that cultural diversity negatively effects group functioning, leading to or being an antecedent of conflict (Vodosek 2005, 2007; Kankanhalli et al. 2006; Wickramasinghe and Nandula 2015). In addition it is stated that cultural diversity lowers team satisfaction, commitment (Vodosek 2005) and increases stereotyping, prejudices, generalizations (Kankanhalli et al. 2006) as well as the intention to quit (Vodosek 2005). Contrasting research findings support the general statement that cultural diversity increases conflict, but in regards to task conflict, this is claimed to have positive effects due to the rise in experiences and discussions (Liu et al. 2008; Paul and Ray 2013). Other types of diversity, based on less obvious aspects, such as tenure or value and beliefs also lead to negative reactions in form of decreased satisfaction and commitment and result in increased conflicts within teams (Mannix and Neale 2005; Jehn et al. 1999; O'Reilly et al.).

\section{$4 \quad$ Way to Deal With Diversity}

Considering the negative consequences of diversity, mainly in terms of conflict, the question can arise whether diverse teams should be aimed for or if segregated markets and firms, as suggested by Becker (1993) could be more beneficial. Especially when considering the finding of my research that each conflict bears hidden or obvious costs, which are claimed to be the highest reducible costs of businesses today (Buss 2011). Within my research of conflict and diversity, there is a strong support for diverse teams, even though I am researching the negative consequences and costs of conflict. However, it is important to point out that these research findings do not have the aim to question diverse workgroups, but to point out the challenges in order to manage these teams correctly. There are already a number of research findings, pointing out mediating factors on how to overcome or at least mitigate some harmful consequences. The investment in human capital, as suggested by Becker (1993) can be one option, while leaving it unevaluated if people actually always consider the costs and benefits of it. It 
needs to be stated that several other factors, such as national variety (Ayub and Jehn 2014), trust (Parayitam and Dooley 2007) or positive emotions (Shah and Jehn 1993) can influence group processes and outcomes positively. Ayub and Jehn describe national separation in form of social distance and national stereotypes and national variety in form of the numerical composition of a group and point out the importance of variety. Within their study they found support that high national variety caused less conflict and higher performances, despite national separation. In case of sex diversity, it was also stated that the proportions between men and women mattered, because in case of men working in predominantly female jobs they did not experience a hostility as the other way around. Stereotyping was also higher in male dominated groups than in female teams (Phillips and O'Reilley 1998).

\section{Conclusion}

Becker (1993) challenged in his work the traditional theory of rational choice and highlights the need to incorporate a much broader set of variables within the theory. Even without the attempt to fully judge his work, it can be concluded that pointing out the need for re-thinking the traditional rational theory was a first important step. However, considering the findings of discrimination at the workplace, times have changed and diversity has become more natural, even though there is still discrimination taking place. By evaluating the key theories of diversity and the effects on group functioning, mainly in terms of conflict, it can be concluded that even without the preference or support of discrimination, every single person is endangered to at least partially discriminate or under evaluate minorities or so-called outgroup members; thus, also highlighting the actual irrationality of people. Diverse teams bear many challenges, which need to be carefully managed and dealt with to reach the benefits of diversity, while keeping the costs of it in terms of conflict or other negative results such as performance declines low. First ideas have already been presented by scholars how to overcome some of these challenges, by pointing out the importance of trust, variety or national composition amongst others. Scholars and businesses should focus more on these variables to come up with sustainable solutions for diverse teams in form of nationality, sex and other attributes. One opportunity which is brought up by Becker's findings (1993) is the calculation of the costs of discrimination. Considering these costs and comparing them with the additional costs of conflict management or the management of diverse teams in general, can foster the opportunity of higher investments in it, without seeing these costs as lost profit. Despite the controversial findings of Becker (1993) the comparison of discrimination costs against the costs for successful management of diverse teams, including conflict management can be seen as a huge opportunity, especially for businesses nowadays, where the globalization fosters diversity. Becker (1993) however highlights the difficulty to measure discrimination costs, so further research could step in here and investigate on better measurements than salaries on how to address this topic. 


\section{References}

Alagna, S.; Reddy, D.; Collins, D. (1982): Perceptions of functioning in mixed-sex and male medical training groups. In Journal of Medical Education 57, pp. 801-803.

Ayub, N.; Jehn, K. (2014): When diversity helps performance: Effects of diversity on conflict and performance in workgroups. In International Journal of Conflict Management 25 (2), pp. 189-212.

Barnlund, D.; Harland, C. (1963): Propinquity and prestige as determinants of communication networks. In Sociometry 26, pp. 467-479.

Becker, Gary S. (1993): The Economic Way of Looking at Behavior. In The Journal of Political Economy 101 (3), pp. 385-409.

Burt, R.; Reagans, R. (1997): Homophily, legitimacy, and competition: Bias in manager peer evaluations. In Working Paper, Graduate School of Business.

Buss, Helmut (2011): Controlling Conflict Costs: The Business Case of Conflict Management. In Journal of the International Ombudsman Association 4 (1).

Byrne, D.; Clore, G.; Worchel, P. (1966): The effect of economic similaritydissimilarity as determinants of attraction. In Journal of Personality and Social Psychology 4, pp. 220-224.

Byrne, Donn (1971): The Attraction Paradigm. New York, NY: Academic Press.

Cross, E.; Katz, J.; Miller, F.; Seashore, E. (1994): The promise of diversity. IL: Irwin: Burr Ridge. 
Jackson, S.; Stone, V.; Alvarez, E. (1993): Socialization amidst diversity: Impact of demographics on work team oldtimers and newcomers. In Research in Organizational Behavior 15.

Jehn, K. A.; Northcraft, G. B.; Neale, M. A. (1999): Why differences make a difference: A field study of diversity, conflict, and performance in workgroups. In Administrative Science Quarterly 44, pp. 741-763.

Kankanhalli, Atreyi; Tan, Bernhard C.Y.; Wei, Kwok-Kee (2006): Conflict and Performance in Global Virtual Teams. In Journal of Management and Information Systems 23 (3), pp. 237-274.

Liu, Yongmei; Luo, Manling; Wei, Xuhua (Eds.) (2008): The Effects of Cultural Diversity, Conflict and Conflict Management on Performance in Global Virtual Teams.

Mannix, E.; Neale, M. A. (2005): What differences make a difference? The promise and reality of diverse teams in organizations. In American Psychological Society 6 (2), pp. 31-55.

O'Reilly, C.; Snyder, R.; Boothe, J.: Effects of executive team demography on organizational change. In G. Huber ad W. Glick (Eds.), Organizational change and redesign, pp. 147-175.

Parayitam, S.; Dooley, R. S. (2007): The relationship between conflict and decision outcomes: Moderating effects of cognitive- and affect-based trust in strategic decision-making teams. In International Journal of Conflict Management 18 (1), pp. 42-73.

Paul, Souren; Ray, Sumati (Eds.) (2013): Cultural Diversity, Group Interaction, Communication Covergence, and Intra-group Conflict in Global Vir- 
tual Teams: Findings from a Laboratory Experiment. 46th Hawaii International Conference on System Services.

Pelled, L.; Eisenhardt, K.; Xin, K. (1999): Exploring the black box: An analysis of workgroup diversity, conflict, and performance. In Administrative Science Quarterly 44, pp. 1-28.

Phillips, K. W.; O'Reilley, C. A. (1998): Demography and Diversity in Organizations: A Review of 40 Years of Research. In Research in Organizational Behavior 20, pp. 77-140.

Shah, P. P.; Jehn, K. A. (1993): Do friends perform better than acquaintances? The interaction of friendship, conflict, and task. In Group Decision Negotiation 2, pp. 149-165.

Tajfel, H. (1981): Human groups and social categories: Studies in social psychology. Cambridge, England: Cambridge University Press.

Tajfel, H. (1982): Social identity and intergroup relations. Cambridge: Cambridge University Press.

Thomas, D.; Ely, R. (1996): Making differences matter: A new paradigm for managing diversity. In Harvard Business Review 74, pp. 79-90.

Triandis, H.; Kurowski, L.; Gelfand, M. (1994): Workplace Diversisty. In Consulting Psychologists Press 4, pp. 769-827.

Turner, J. (1987): Rediscovering the social group: A social categorization theory. Oxford, UK: B. Blackwell.

Vodosek, Markus (2005): Cultural diversity, intragroup conflict, and group outcomes: Evidence for a mediated relationship. In Academy of Management Best Conference Paper. 
Vodosek, Markus (2007): Intragroup conflict as a mediator between cultural diversity and work group outcomes. In International Journal of Conflict Management 18 (4), pp. 345-375.

Wickramasinghe, V.; Nandula, S. (2015): Diversity in team composition, relationship conflict and team leader support on globally distributed virtual software development team performance. In Strategic Outsourcing: An International Journal 8 (2/3), pp. 138-155.

Williams, Katherine Y.; O'Reilly, Charles A., III (1998): Demography and diversity in organizations: A review of 40 years of research. In Research in Organizational Behavior 20, pp. 77-140. 